\title{
B. BY COMMISSIONS AND SUB-COMMISSIONS
}

Of the Resolutions and Recommendations adopted by Commissions and Sub-Commissions only those of wide interest and appeal are repeated here; the others may be found in the Reports of Meetings to which reference is made. The numbers of the Resolutions, where given, are those used in the Reports.

Commission 4 -see page 167 . (See also Commission 31 .)

2. The provisional value of ephemeris time that is obtained by comparing the Moon's mean longitude, given by observations, referred to the equinox of FK 4, with the positions tabulated in the Improved Lunar Ephemeris is denoted by E.T.о. The difference E.T.о.-U.T.2 is denoted by $\Delta T_{0}$.

\section{Commission 5 -see page 168 .}

Concerning the proposed new edition of Les Observatoires astronomiques et les Astronomes, Commission 5 intends to form a Working Group, consisting of the President of the Commission, Professor P. Bourgeois and Dr G. Z. Dimitroff, to co-ordinate as efficaciously as possible the efforts of all working in this field. It calls on the General Secretary of the Union to request representatives from different countries to make themselves responsible for the assembly and verification of the necessary data.

Commission 5 reminds all observatories and institutions which publish astronomical works that they have been requested to send regularly two copies of each publication to the editors of the Referativny fournal (Moscow), of the Astronomischer Fahresbericht (Heidelberg), and of the Bulletin signalétique du CNRS (Paris), in order to facilitate the preparation of these bibliographical periodicals and to ensure an exhaustive analysis of existing publications.

\section{Commission 7 -see page 173 .}

Commission 7 recommends a unified notation for the Earth's gravitational field; details are not repeated here.

\section{Commission 8 -see page $\mathrm{I}_{7} 8$.}

Commission 10-see page 189 .

Commission Io, considering the wish expressed by the Comité International de Géophysique and other organizations for world-wide co-operation in geophysics, urges all observers active in the solar patrol to report promptly to the nearest Regional Warning Centre, by telegram or other available fast channel, all flare events of importance $I+$ and greater, during the coming years of declining solar activity and especially during the International Year of the Quiet Sun (IQSY).

\section{Sub-Commission ro $a$-see page r $9 \mathrm{I}$.}

The Sub-Commission notes with satisfaction the effectiveness of the co-operative solar flare patrols of the IGY and the IGC-I959, and the continued co-operation of many observing stations in voluntary cinematographic flare coverage and data centralization; the Sub-Com- 
données précises relatives aux éruptions solaires, et d'une surveillance des autres phénomènes à début brusque observables en $\mathrm{H} \alpha$, pendant la période de l'AISC et durant le minimum de l'activité solaire; la Sous-Commission recommande par suite la poursuite des efforts en vue d'une étude complète des éruptions et du disque, par une coopération internationale. La SousCommission note en particulier l'importance qu'il y a à combler les principaux temps morts grâce au renforcement de la surveillance continue exercée de Chine, d'U.R.S.S., d'Inde, d'Amérique Latine et des régions orientales de l'Amérique du Nord; elle recommande de plus la préparation par les Centres Mondiaux de Données d'un catalogue complet des films disponibles aux différentes stations.

La Sous-Commission recommande la préparation par les Centres Mondiaux de Données d'un catalogue, établi d'une façon coopérative, pour les enregistrements issus des radiotélescopes solaires à balayage de fréquence, couvrant tous les domaines de longitudes, et insiste sur la grande importance, pour la physique solaire, la physique spatiale et les recherches sur les relations Soleil-Terre, de la coopération internationale la plus large possible afin d'assurer le caractère exhaustif de l'ensemble des observations.

Commission 15 -voir page 228.

Commission 16 -voir page 234 .

La Commission 6 recommande l'adoption de conventions dans l'établissement de nouvelles cartes lunaires et de règles pour la nomenclature des différents détails lunaires (les détails ne sont pas reproduits ici).

3. Le comité de la Commission 16, "Coopération Internationale pour l'Observation des Planètes", désire faciliter cette coopération par l'établissement éventuel d'au moins deux centres de documentation, l'un aux Etats-Unis, l'autre en Europe; dans ce but il demande aux observatoires disposant de grandes collections de photographies planétaires de les rendre disponibles pour de telles études, vu la nécessité d'une répartition complète en longitude.

Commission 17 -voir page 254 .

Commission 20-voir page 262.

Commission 21-voir page 264.

La Commission $2 \mathrm{I}$ insiste pour que des chambres susceptibles d'étudier l'ensemble de la voûte céleste soient montées, sans fonctionner, dans toutes les stations d'étude du ciel nocturne même à des latitudes géomagnétiques aussi basses que $30^{\circ}$. Elles devraient être mises en fonctionnement dans les rares occasions où des aurores sont visibles.

Commission 22-voir page 271 .

Commission 23-voir page 274 .

Commission 24-voir page 278.

La Commission 24 exprime le vœu que le catalogue complet de mouvements propres trouvé dans l'étude générale de mouvements propres de Bruce (Bruce Proper Motion Survey) soit publié in extenso et distribué à tous les observatoires. Jusqu'à présent, ce catalogue n'a été publié que sous une forme miméographée et seulement en tirage limité. 
mission also notes the increasing demand for accurate solar flare data and for patrol of other abrupt solar $\mathrm{H} \alpha$ phenomena during the IQSY period, and through the solar activity minimum; the Sub-Commission therefore commends continued efforts towards complete flare and disk coverage on a co-operative international basis; the Sub-Commission notes in particular the importance of filling the major time gaps by further patrol coverage from China, the U.S.S.R., India, Latin America and Eastern North America; it further urges preparation by the World Data Centers of a full catalog of films available at co-operating stations.

The Sub-Commission recommends the preparation by the World Data Centers of a cooperative catalog of records of swept-frequency solar radio noise telescopes, covering all longitudes, and emphasizes the great importance to solar physics, space physics, and solarterrestrial research of the widest possible international co-operation to assure full observational coverages.

Commission $\mathrm{I}_{5}-$ see page 228 .

Commission I6-see page 234 .

Commission 16 recommends conventions for use in compiling new maps of the Moon, and rules for the nomenclature of lunar features; details are not repeated here.

3. The committee appointed by Commission 16 on "International Collaboration for Planetary Observations" desires to facilitate international collaboration on planetary studies by the eventual establishment of at least two data centers, one in the United States and one in Europe; and meanwhile requests observatories having large collections of planetary photographs to make these available for such studies as require a full coverage in longitude.

Commission 17 -see page 254 .

Commission 20-see page 262.

Commission $2 \mathbf{I}$-see page 264.

Commission 21 urges that inactive all-sky cameras be set up at night-sky stations even in geomagnetic latitudes as low as 30 degrees. They should be put into operation on rare occasions when auroras are visible.

Commission 22-see page 27 I.

Commission 23-see page 274 .

Commission 24-see page 278 .

Commission 24 expresses the wish that the complete catalog of proper motions found in the Bruce Proper Motion Survey be fully published and distributed to all observatories. The catalog has up to this time been published in mimeographed form and only in a limited edition. 
Commission 26-voir page 286.

Dans le Compte-Rendu de la Commission 26, sont reproduites les résolutions adoptées au Symposium No. 17 de l'UAI (Etoiles doubles visuelles).

Commission 27-voir page 289 .

Commission 28-voir page 303 .

Sous-Commission 29 c-voir page 321 .

Commission 31-voir page 329. (Voir aussi Commission 4.)

I. La valeur provisoire du temps des éphémérides, obtenue en comparant la longitude moyenne de la Lune résultant d'observations rapportées à l'équinoxe du FK 4 , avec les positions données par l'Improved Lunar Ephemeris est appelée T.E.o. La différence T.E.o. - T.U.2 est appelée $\Delta T_{0}$.

3. On recommande le lancement de satellites artificiels de haute altitude qui puissent être utilisés pour les expériences sur le caractère fondamental du temps.

Commission 37-voir page $34^{\circ}$.

Commission 40 -voir page 354 .

4. Considérant que l'attribution exclusive de canaux de fréquences pour la radioastronomie est essentielle au développement et au succès de cette branche de l'astronomie; que, pour être efficace, un tel canal, d'une largeur d'au moins $\mathbf{I} \%$, devrait être utilisable dans chaque octave, d'une façon cohérente avec les discussions antérieures se référant à des fréquences particulières; qu'à l'heure actuelle l'attribution à l'échelle mondiale d'un seul canal a été l'objet d'un accord;

la Commission 40 propose que toutes les démarches possibles soient entreprises pour inclure la radioastronomie dans l'ordre du jour de la conférence radio extraordinaire de caractère administratif projetée par l'I.T.U. en 1963 , et que des dispositions soient prises pour faire à la radioastronomie des attributions de fréquence, approximativement dans chaque octave du spectre, et ce à l'échelle mondiale.

Commission $4 \mathbf{1}$--voir page 356 .

I. La Commission $4 \mathrm{I}$ exprime le vou de voir les Comités Nationaux d'Astronomie des pays adhérant à l'Union organiser, partout où cela sera possible, des commissions sur l'Histoire de l'Astronomie, afin de coordonner les efforts des chercheurs dans des domaines voisins.

Commission 44 -voir page 389 .

I. La Commission 44 recommande qu'en sus des projets d'expériences astronomiques spatiales de grand intérêt scientifique qui ont déjà été prévues, attention soit portée au lancement d'une fusée-sonde au voisinage immédiat d'une comète. 
Commission 26 - see page 286.

In the report of the meeting of Commission 26 are given the resolutions adopted at IAU Symposium No. 17 (Visual Double Stars).

Commission 27-see page 289 .

Commission 28-see page $3 \circ 3$.

Sub-Commission $29 c$ - see page 321 .

Commission $3^{\mathrm{I}}$-see page 328 . (See also Commission 4.)

I. 'The provisional value of ephemeris time that is obtained by comparing the Moon's mean longitude, given by observations, referred to the equinox of $\mathrm{FK}_{4}$, with the positions tabulated in the Improved Lunar Ephemeris is denoted by E.T.o. The difference E.T.o.-U.T.2 is denoted by $\Delta T_{0}$.

3. It is recommended that high-altitude satellites be launched which can be used for experiments concerning the fundamental nature of time.

Commission 37 -see page $34^{\circ}$.

Commission $40-$ see page 354 .

4. Considering that the exclusive allocation of channels for radio astronomy is essential for the successful pursuance of this branch of astronomy; that in order to be effective one such channel, having a width of at least $\mathbf{x} \%$, should be available in every octave consistent with earlier discussion relating to specific frequencies; that at present only one world-wide allocation of a channel has been agreed upon;

proposes that all possible steps be taken to include radio astronomy in the agenda of the proposed extraordinary administrative radio conference of ITU in 1963 ; and that steps be taken to make allocations for radio astronomy approximately in each octave of the spectrum on a world-wide basis.

Commission $4 \mathrm{I}-$ see page 356 .

I. Commission $4 \mathrm{I}$ expresses its desire that the National Committees of Astronomy in countries adhering to the Union should organize, wherever possible, commissions on the History of Astronomy in order to co-ordinate the efforts of scientists in allied fields.

Commission 44 -see page 389 .

1. Commission 44 recommends that, in addition to the plans for astronomical space experiments of high scientific interest which have been already planned, consideration be given to the launching of a space probe into the close vicinity of a comet. 